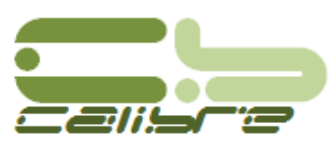

\title{
Outer Space Law: A Human Future
}

\author{
Nilo Serpa ${ }^{1}$, Richard Cathcart ${ }^{2}$ \\ ${ }^{I}$ Centro Universitário ICESP, Águas Claras, Brasília, Brasil DF. \\ ${ }^{2}$ GEOGRAPHOS, Burbank, California USA.
}

Corresponding author: nilo.serpa@icesp.edu.br

Received:_16 Apr 2021_/ Accepted:_04 May 2021_/ Published:_28 Jul 2021_.

\begin{abstract}
Present paper discusses critical aspects of the colonization of outer space in view of the broad and robust law required in accordance with democratic ideals. The article also addresses ethical issues touching planetary environmental preservation especially in the event of alien life - as well as relevant topics relating to future terraforming projects.
\end{abstract}

Key-words: outer space law, ethics, terraforming, alien life.

Resumo: O presente trabalho discute aspectos críticos referentes à colonização do espaço exterior em vista da ampla e robusta legislação requerida em conformidade com os ideais democráticos. O artigo também aborda questões éticas tocantes à preservação ambiental planetária - especialmente na eventualidade de existência de vida alienígena — bem como tópicos relevantes relativos a futuros projetos de terraformação.

Palavras-chave: lei do espaço exterior, ética, terraformação, vida alienígena.

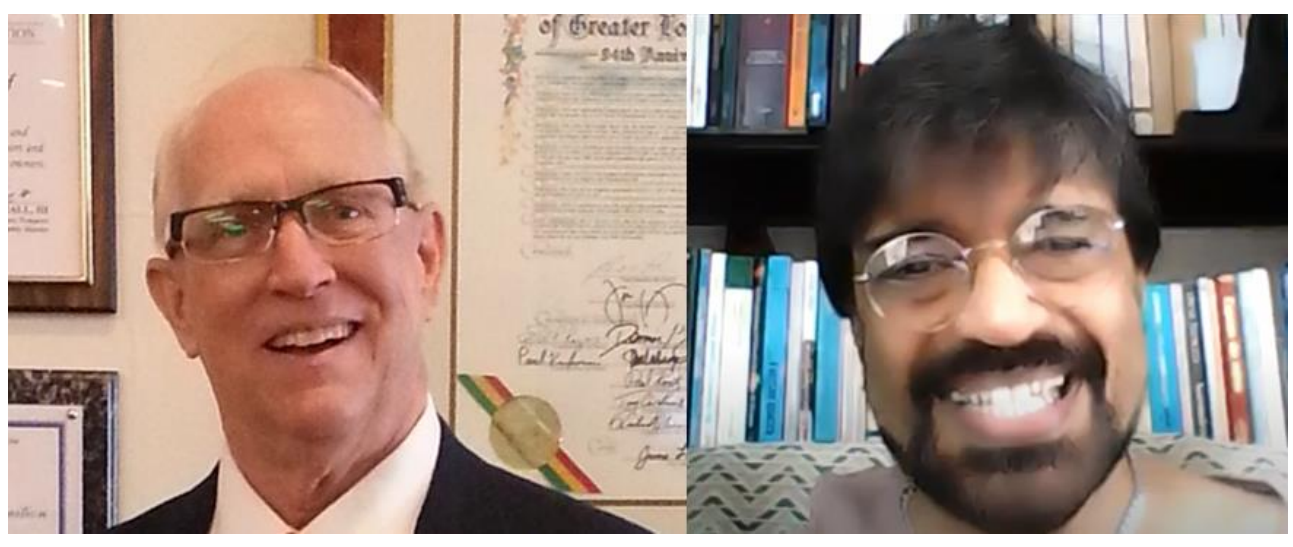

by Cathcart and Serpa, 2021.

CALIBRE - Revista Brasiliense de Engenharia e Física Aplicada, ISSN 2526-4192.

Livre direito de cópia de acordo com os princípios estabelecidos pela Creative Commons. 


\section{Introduction}

When we eventually gaze at the luminous nighttime sky (an increasingly forgotten after-sundown habit for most urbanized people!), the last passing thought that occurs to us is to ask what we shall enforce under the exercise of the commonly accepted codified law when we are really in orbital position to significantly occupy the remainder of outer space - i.e., the Universe. It is understood that the expression "significantly occupy outer space" refers to the establishment in our Solar System of colonies on the Moon, Mars, and other celestial bodies within the reach of our extant space technology, still in its infancy ${ }^{1}$.

In fact, such concerns seem possibly premature, judging by the mega-problems we face in our day-to-day lives within the Earth. However, the issues involved create such a complex storyline that, if we do not start early the arduous task of devising an extensive body of laws that encompass all intertwined economic, ethical, social and cultural aspects, we shall never achieve a just and consolidated rule of law for that future which shall, it is to be hoped, inexorably come, sooner or later.

Why would humans colonize outer space? A laconic answer would be simply because a vast volume of outer space surrounds us. But the fact is that we have no option for our own nature; the world shall be exhausted because we are a devastating and compulsive species. We are consumers of resources at unsustainable rates, and there is no indication that this mental inclination and geophysical habit will change in the short term needed, unless we are definitively on the brink, self-known to be a declining species. Carl Sagan, undoubtedly one of the best minds of the 20th century, has always been an enthusiast of outer space exploration: "When I assess the facts, the usefulness of planetary exploration seems to me to be superlatively practical and urgent for us." (Sagan, 1994/2019) (authorial free translation). Elon $\mathrm{Musk}^{2}$, a notable figure in the burgeoning international outer space

\footnotetext{
${ }^{1}$ We are aware of current theories that subsidize potential technologies for space travel (as a rule, based on $a b$ initio propositions supported by General Relativity framework), and we have noted some optimism about the possibilities for interstellar travel in perhaps 100 or 200 years. We respect the optimists even because today it is very difficult to predict which technological jumps we will take in relatively short periods; we are not trying to rain on its parade, but it is doubtful we will find any solution that could take us beyond the Solar System in an efficient and pragmatic way in that period; we think that, for a long time, we shall have to be content with the orbs of our modest primary, since having a look at some of the reported interstellar-type technologies, weakly aided by presentday theories, we see they require science which goes far beyond anything our best scientists can make real. Perhaps, 500-1,000 years ahead from where we are now one can see a powerful vehicle for extra-solar travels (it's possible, of course, but it would be surprising if we actually do find any technology before this time).

2 The reader who wishes to know more can access Tony Shepherd and Jamie Seidel, 'Elon Musk Unveils Lofty Vision at International Astronautical Congress in Adelaide to Pay His Way to Mars', The Advertiser (online), 29 September 2017 <https://www.adelaidenow.com.au/news/south-australia/elonmusk-to-detail-his-mission-to-marsat-international-astronautical-congress-inadelaide-on-friday/news-story/53708c3d16e4070a66aab3d0b8b7477a>.
} 
exploration and exploitation industry, recently concluded that humans need to reach the stars if our species wants to prevent the extinction of humankind (Kaku, 2018). Stephen Hawking, the great physicist of the "Theory of Everything", on several different occasions verbalized profoundly what he thought about the colonization of other potential worlds: "We need to explore the solar system and find other places that are compatible with human life. [...] Human colonization of other planets is no longer science fiction and very soon it may become a scientific fact. [...] If humanity wants to continue to exist 1 million years from now, our future is to go where no one has ever been." (Hawking, 2018) (authorial free translation). But nothing guarantees that humans shall even exist for a long time. It seems that we have already made the choice for a lifestyle that is uncommitted to the future; after all, the principle of self-determination, which summarizes peoples' right to dispose of their own destiny, logically emanates from democratic legitimacy (Aron, 1962/2018). Ironically, the same democratic thinking that ensures individual and collective freedom can lead us to extinction! Therefore, presumed human evolution with real social progress is unknown today. As A. Huxley said, "... it depends on us and there is nothing in the change process itself that makes it mandatory." (Huxley, 1952/2018) (authorial free translation). In "War and Peace", Leo Tolstoy already considered that with the kind of unequal social organization we have, any basic scientific advance will strengthen the power of the ruling minority over the majority (Tolstoy, 1869/2008). This perception leads us to fear that, no matter what scientific and technological advances we achieve, we will maintain our despotic and selfish vices inherent to humans as a species wherever we are located in the known Universe. In face of the immense challenges that seem to be arising from 2021 onwards, and knowing somewhat the human spirit with its most obvious weaknesses and strengths, it seems apparent, even evident, for the need for laws that establish order and justice in the occupation of the universal outer space, if it actually happens in our species' future, also seeking to extend the benefits of science to everyone, indiscriminately.

\section{Space Law: State of the Art}

Space Law is an embryonic theme, full of vagaries and inconclusive and contradictory espoused doctrines. In spite of the presence of pioneering authors such as Manfred Lachs (1972), Carl Q. Christol (1982, 1991), Stephen Gorove (1977, 1991), Bin Cheng (1997), and more recently Frans von der Dunk (2015), the existing contemporary published literature is still relatively scarce and strongly academic in tone, with a huge open field of work (undoubtedly, it is necessary to recognize the value of universities, teaching space law and encouraging its development). A widely recommended reading is the Second Edition of Francis Lyall and Paul B. Larsen's fresco "Space Law: A Treatise" (2018). Currently, the most emblematic issues related to the theme are summarized in the so-called "Five Outer Space Treaties", of which we are particularly interested in the "Treaty on Principles Governing the Activities of the States in the Exploration and use of Outer Space", including the Moon and Other Celestial Bodies, opened for signature 27 January 1967, 610 UNTS 205 (entered into force 10 October 1967) ('Outer Space Treaty'). Other related deeds also participate of the evolution of Space Law, including the 
"Convention of the International Telecommunications Union", the "United Nations Charter", the "1963 Partial Test Ban Treaty", and less global treaties as regional conventions grouping different national space agencies such as the "Convention of the European Space Agency" (1975).

Although it is desirable that, as a remarkably intelligent species, humans should view the occupation of outer space with a less aggressive approach from the viewpoint of the current dominant competitive market model, the future seems somewhat dystopian, and it would be precarious to imagine that there shall be no new outer space competition, whilst in a different mode than during the decades of the geopolitical global Cold War. In addition, the rules currently assumed by the proposed laws give rise to a broad conundrum. For instance, on one level Article II of the Outer Space Treaty declares that claims of sovereignty over parts of outer space are prohibited; from this, we may suppose that any state claiming an entire planet, or considerable part of a planet, shall strongly be condemned. On another level, the mining of any planet resources is being proposed as an acceptable use of outer space's object-content; certainly, such exploration would require the exercise of possession and control of the materials found by an entity that, after all, would be claiming sovereignty. Thereby, the precise scope and application of Article II's content remains an open question. This is a fundamental issue, taking into account that the required enterprises demand proportionally astronomical costs, and should involve large international consortia. We shall need very clear laws regarding the shares to be returned to each participating nation in proportion not only to the share of participation but to the nature of the contribution. For example, Brazil could specialize in large-scale food production technologies (local and off-planet), and the law would need to address in its precepts the essentiality of such a role.

\section{Terraforming Mars (and beyond...)}

Furthermore, the issue becomes more delicate when addressing the rules and regulations on the use of terraforming technologies. To terraform means to replicate in another orb - i.e., an object with malleable and valuable contents - the necessary conditions amenable for, ultimately, common outdoor human habitability which are indubitably present on planet Earth, our homeworld (in fact, soon we may need to geoengineer Earth itself!). General aspects of terraformation can be found in Serpa (2017), and soon in Serpa \& Cathcart (2021) to appear in Martin Beech's collaborative book "The Colonization and Terraforming of Mars" (see references). Also, to be published in the same collectanea, authors such as Stoner (2021), Smith (2021) and Szocik (2021) discuss the legal and ethical aspects of Earth-shaping the so-called ruddy planet of Mars in a timely manner. There are two classes of terraformation, namely I- local terraformation (only selected parts of a planet constitute habitable micro-environments, as a rule, encapsulated in technological "bubbles"), and II- global terraformation (the entire planet is gradually converted into a useful environmental near-replica of the Earth). Local terraformation can take 


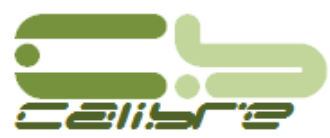

part in a mega-project as the first phase of global terraformation, supporting the latter, which can effectively last for centuries (Cathcart, 2014).

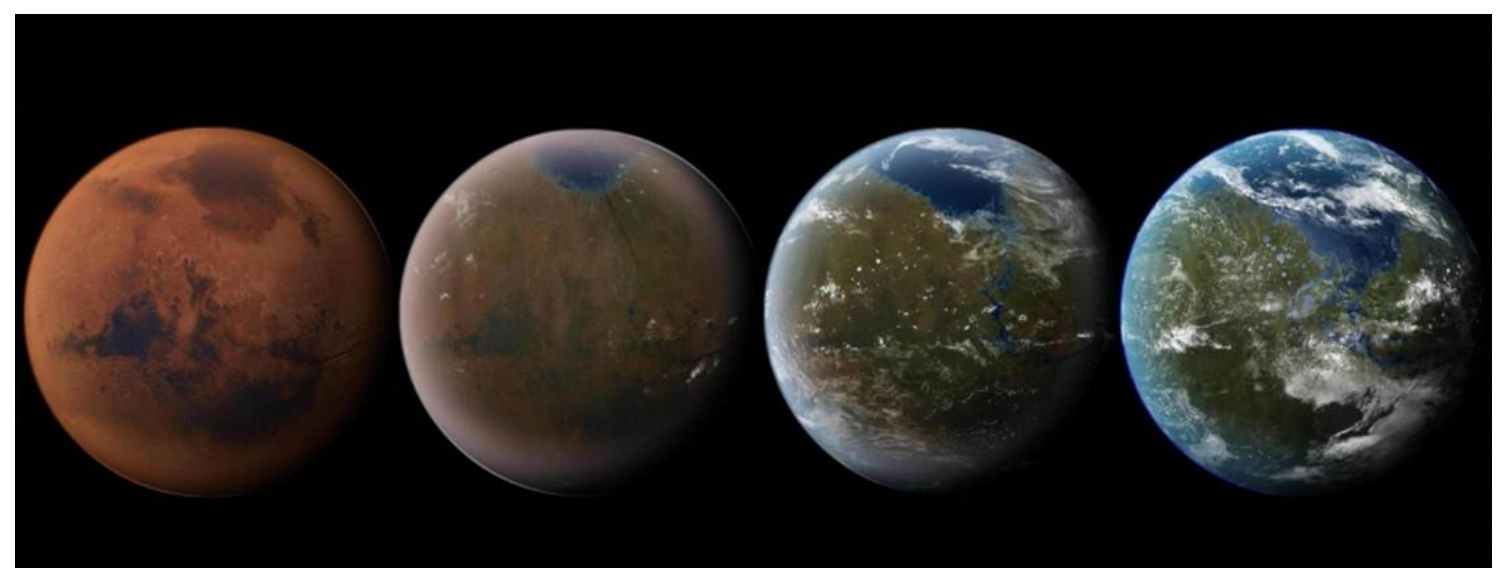

Although the terraforming of "Red Planet" Mars is, in theory, currently within humanity's maximal expression technological capabilities, investments in this field are prohibitive for now, but, in the case of Mars, one can in principle rely on the local exploitation of iron for mega-engineering and, most likely, getting purified water from Mars's observed polar zone permafrost, both for direct consumption, and industrial-scale extraction of oxygen and hydrogen gases. Indeed, we may presume there shall certainly be a tendency to establish geopolitics of freshwater sources on Mars, as it exists today in the former basin of the almost completely extinct Aral Sea (Mcdermid \& Winter, 2017), where the Central Asian republics dispute the freshwater resources from the Tien-Shan mountain system of that is directed to irrigate the famous Fergana Valley. Here, international planetary law shall need to enforce very clear rules regarding the right to use and distribute freshwater-based, perhaps, on a special system of conferment, otherwise, we would repeat absurdities such as the diversion of natural water-courses to serve the private interests of the wealthy and powerful states such as China versus India in the Himalayas.

Many legal aspects need to be discussed here, especially nowadays when commercial exploitation of the Moon, asteroid mining and Mars alterations by the technically competent launching States — far beyond the scientific cause - starts to appear in heated cross-talk and formal discussions, and much of the current law of outer space is solely restricted to the limits of the only orbital activities, leaving a great void on property ownership, maintenance and disposal issues and exploitation rights within other celestial bodies gravitational influence. First, space law must ensure that, for type I terraformation, all technological "bubbles" must offer the same parameters of environmental quality and biosafety to all its intentional inhabitants — including plants and animals without which human life would be unmaintainable —, regardless of cultural, economic or any kind of differences that may exist among various people. Also, space law must state that every exploration activity should generate counterparts in 
resources for science, as well as for the so-called social technologies, both with a wide range of coverage, insuring accessibility. So far, there is but a pale light on this important matter, a brief statement in the "United Nations Treaties and Principles on Outer Space" (UNITED NATIONS, 2008) that seems to indicate a democratic vision of the uses of outer space, and could add something to this concern: the "Declaration on International Cooperation in the Exploration and Use of Outer Space for the Benefit and in the Interest of All States, Taking into Particular Account the Needs of Developing Countries". The macro-problem is that, on this scale of law, there is not extant any organization with global representation, not even the United Nations, which has always functioned as a pro forma geopolitical organization since its early- $20^{\text {th }}$ Century establishment.

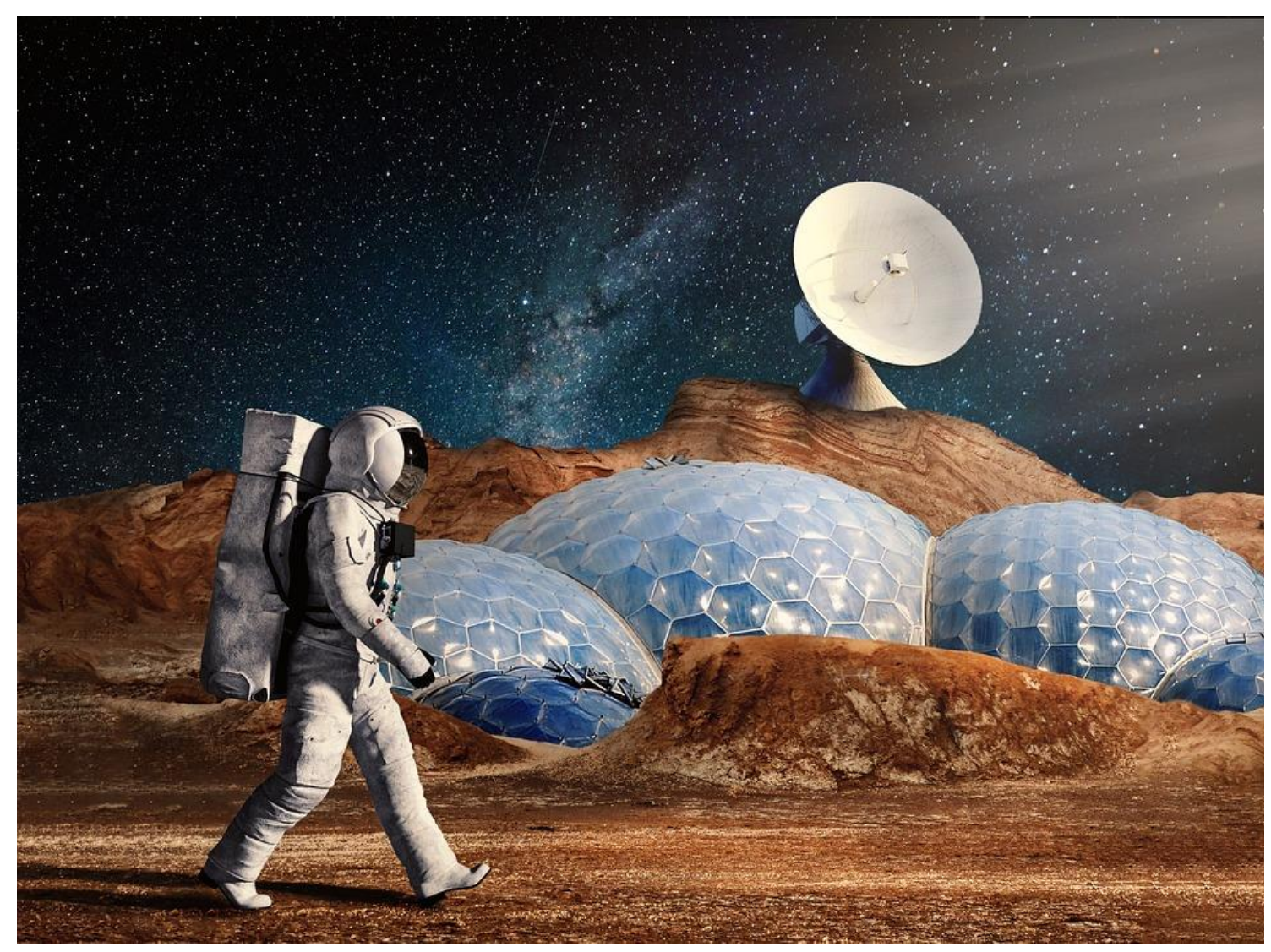

An important feature, treated superficially in Article VII of the "Outer Space Treaty", is that the ability to claim damages from another in the event of an accident (to be expanded to include all vastly consequential geoengineering and terraforming accidents) needs to be defined and, thus, exposed in detail by the fully developed international legal regime, making clear the consequences of determined wrongful acts. In addition, the legal requirements for starting terraforming activities must specify the benefits and the social scope of the enterprise as 
a whole, alongside the basic scientific and technologic premises of work safety for everyone directly involved in the execution of the mega-engineering project's public-works.

\section{Epistemic security: here and now a problem}

Eugenic ideas, radical populist ideologies (Fuentes, 2020) and fundamentalisms of all kinds appear whenever an epistemological rupture is revealed publicly, sometimes even announced via news media. This epistemological break - caused by changes in value judgments, replacement of theoretical models hitherto accepted, acquisition of new knowledge that changes the group and popular worldview - accentuates the feeling of uncertainty inherent in our everyday lives. The wide uncertainties of human life-style favor the control of these disruptions by a small heeded minority. The Covid-19 pandemic of 2020 exemplifies this very well, showing all the facets of a rupture in the shared set of our common beliefs: anti-vaccine fanatics, hypocrites who say they are against vaccination to manipulate groups of people, but who are secretly vaccinated, counterfeiters of commercially sold health products, fraudsters in purchasing processes, messianic false prophets and a whole global Internet network at the service of disinformation. All this fits the obscure interests of focused corporate conclaves of profiteers that benefit from the conundrum (controlling and standardizing the format of the information transmitted to our world's public). When the effective occupation of outer space (to the extent that terraforming processes are established) becomes a reality, this shall characterize an unprecedented epistemological rupture, and law and education shall be in the main responsible for the epistemic security in the moments of disruption of our fragile convictions.

Genetic manipulation of humans is already being considered to create a new species adapted to live in outer space. Imagine how frightening the future shall be without ethical and legal limits for such experiments! The law must be prepared to deal with the complexities of a socially and technologically very different world, because the only physiological-psychological constant that shall remain the same is the human way of being; so, law-devisors must look for a non-zero-sum world, where changes are aligned with human values, peaceful purposes and social benefits for all people.

\section{Arriving at a potential human world: is native biota there already?}

The simple discovery of an alien microorganism will already be the reason for an epistemological break with profound consequences in our understanding of the Universe. The point is: what to do when faced with alien life in the target orb of our human-centric terraforming policies? We think that the law of outer space has a lot to say 
about it, and must do it now, because judging from what we have witnessed here on Earth, it is likely that we will have few scruples about "trampling the flowerbed of others".

Although so far there is no concrete evidence of the existence of life outside the Earth, still less of the existence of more or less equivalent-to-human extraterrestrial intelligences, the presence of SETI as the background of the search for extraterrestrial life and other scientific exobiological research initiatives raises some legal concerns regarding the investigational procedures and interaction rules to be adopted outside the Earth, even in an intuitive manner that anticipates the increasing complexity of the law in face of the possibility of identifying alien organisms of any kind. Moreover, the search for life obeys a primitive impulse — food, curiosity, faith — inherent to living beings. As Sagan said, "We can't refrain it. Life seeks life." (Sagan, 1994/2019) (authorial free translation).

\section{The true face of human nature and the role of law (plus education)}

Strictly speaking, we shall need an intimate combination of law and education. Westerners always turn to the Greeks, especially Aristotle, to remember the fundamental things that constituted their legacy for contemporary civilization (Lawrence-Mathers, 2021). In his reflections on a commonsensical society, with moderate collective habits and far less consumerist fervor that today's, Aristotle went beyond a discourse in favor of the control of real and mobile property, defending rather a balance of human desires by the accumulation of goods: "... It is much more necessary to level the desires of men than their properties, and this can only be achieved by an adequate system of education reinforced by the law." (Aristotle, 335-323 a.C. ?/1986) (authorial free translation). We think how surprising these rewarding ideas are for a so-called "Anthropocenic Era" when slavery was natural! Hopefully it shall be possible for us to bring out the best in education and legislation translated to other Solar System orbs, but honestly, we don't see any such realistic and apprehensive tendency these days

So that, retrieving an example from science fiction, the alien sifter species shown in the Roland Emmerich Independence Day film does not look very different from us after all, at least in amorality and greed for resources. The difference is that we have developed a socio-linguistic and an action device called "hypocrisy" to camouflage our true conscious and unconscious intentions, and, in addition, we admire and adore the superfluous, a fact that leads us, paraphrasing Galloway (2008), to a Faustian pact with technology and with the very science that forms operable technology. Thus, if we replicate on Mars or the Moon the habits we have here on Earth, it shall be a mere matter of time the need for a new modifiable world, who knows Titan, and thus we shall go from world to world, seifing everything we find. Only by virtue of an implacable law and superlative education shall the construction of an orderly, inclusive and unified extra-Earth outer space State be feasible and long-lasting. 


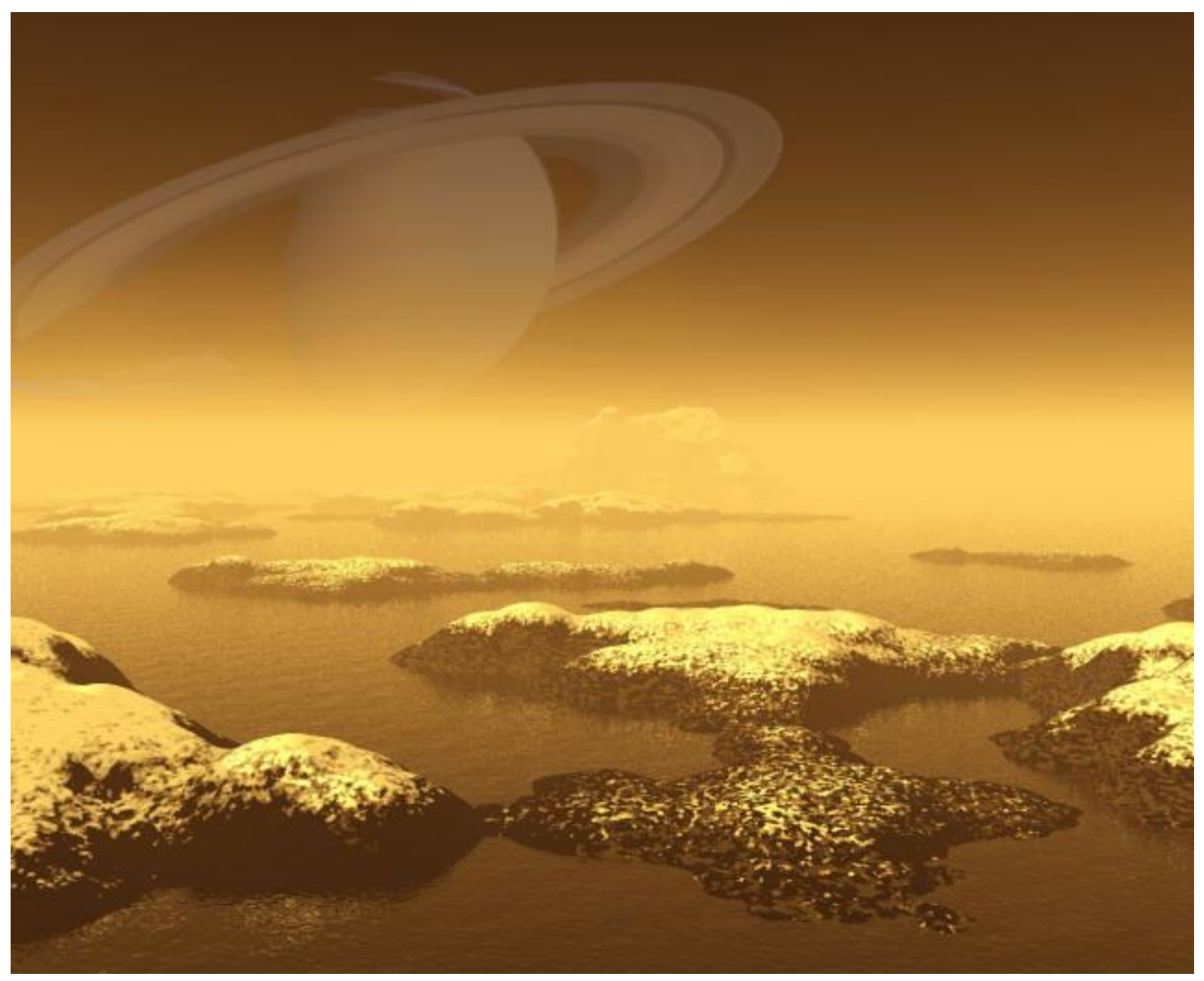

Thus, terraforming laws must be strict with regard to land occupation rates, otherwise there shall not be enough made world for the seemingly uncontrollable human migration and predation. It is important to remember that, although driven largely by the impetus for exploration by the launching States and corporations, the colonization of other Solar System planets is motivated by real survival needs originating from the trail of destruction that we leave here as a lesson on what should not be done and, as well, our ever-increasing certainty of Cosmic debris and celestial events detrimental to all life trapped within the Earth.

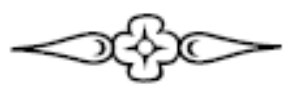




\section{References}

Aristotle (335-323 a.C. ?/1986). Politica: Libro Primero - Capítulo I. Madrid: Aguilar, 1182p.

Aron, R. (1962/2018). Paz e Guerra Entre as Nações. São Paulo: Martins Fontes, 952p.

Bin Cheng (1997). Studies in International Space Law (Oxford University Press).

Cathcart, R. (2014). Medicative Macro-Imagineering: Earth \& Mars Megaprojects. ISBN 10:1495921565. SEE: Chapter 8, "Mediterranean Sea Basin Enclosure and Redevelopment", pages 391- 468.

Christol, C. (1982). The Modern International Law of Outer Space (Pergamon Press).

Christol, C. (1991). Space Law: Past, Present, and Future (Kluwer).

Dunk, F. von der (ed). Handbook of Space Law (Edward Elgar, 2015).

Fuentes, J. (2020). Populism: The Timeline of a Concept. Contributions to the History of Concepts 15: 47-68.

Galloway, J. (2008). Revolution and Evolution in the Law of Outer Space. Nebraska Law Review, 87(2), 516-520.

Gorove, S. (1977). Studies in Space Law: Its Challenges and Prospects (AW Sijthoff International Publishing Company).

Gorove, S (1991). Developments in Space Law: Issues and Policies (Martinus Mijhoff).

Hawking, S. (2018). Breves Respostas para Grandes Questões. Rio de Janeiro: Intrínseca, 255p.

Huxley, A. (1952/2018). A Situação Humana. Rio de Janeiro: Globo, 294p.

Kaku, M. (2018). O Futuro da Humanidade. São Paulo: Planeta do Brasil, 367p.

Lachs, M. (1972). The Law of Outer Space (AW Sijthoff International Publishing Company).

Lawrence-Mathers, A. (2021). Medieval weather prediction. Physics Today. Pages 38-44.

Lyall, F., Larsen, P. (2009/2018), Space Law, A Treatise. Ashgate Publishing Limited (U.K.) (2009) - ISBN 978-07546-9242-3, pp. xiv +596 .

Mcdermid, S., Winter, J. (2017) Anthropogenic Forcings on the Climate of the Aral Sea: A Regional Modeling Perspective. Anthropocene 20: 48-60.

Sagan, C. (1994/2019). Pálido Ponto Azul. São Paulo: Schwarcz, 331p.

Serpa, N. (2017). Terraforming the Aral Sea Basin: Geomorphological and Anthropogenic Foundations. CALIBRE Revista Brasiliense de Engenharia e Física Aplicada, v. 2, p. 17-38, 2017. 
Serpa, N., Cathcart, R. (2021). Terraforming Worlds: Humans Playing Games of Gods. To appear in: Martin Beech (Ed.), The Colonization and Terraforming of Mars, Scrivener Publishing, Beverly, MA.

Smith, K. (2021). Homo Reductio: Eco-nihilism and human colonization of other Worlds. To appear in: Martin Beech (Ed.), The Colonization and Terraforming of Mars, Scrivener Publishing, Beverly, MA.

Stoner, I. (2021). The Ethics of Terraforming: A Critical Survey of Six Arguments. To appear in: Martin Beech (Ed.), The Colonization and Terraforming of Mars, Scrivener Publishing, Beverly, MA.

Szocik, K. (2021). Ethical, political and legal challenges relating to colonizing and terraforming Mars. To appear in: Martin Beech (Ed.), The Colonization and Terraforming of Mars, Scrivener Publishing, Beverly, MA.

Tolstoy, L. (1869/2008). Guerra y Paz. Mondadori Store, 1162p.

UNITED NATIONS (2008). United Nations Treaties and Principles on Outer Space. United Nations Publication Sales No. E.08.I.10 ISBN 978-92-1-101164-7. 